\title{
IMPACT ASSESSMENT OF FACTORS AFFECTING INFORMATION TECHNOLOGY PROJECTS IN RIVERS STATE, NIGERIA
}

\author{
Oluigbo Ikenna Victor ${ }^{1}$, Nworuh Godwin Emeka ${ }^{2}$, Nwokoro Chukwudi ${ }^{3}$ \\ ${ }^{1}$ Graduate Assistant, Department of Information Management Technology, Federal University of Technology Owerri, \\ Nigeria \\ ${ }^{2}$ Professor, Department of Information Management Technology, Federal University of Technology Owerri, Nigeria \\ ${ }^{3}$ PG Scholar, Department of Information Management Technology, Federal University of Technology Owerri, Nigeria
}

\begin{abstract}
The work studies the impact assessment of factors affecting Information Technology (IT) projects in River State. In order to stop the failure of IT projects in River State, three IT projects were examined using some critical success factors to create a check list for a successful IT project. A sample of 85 respondents was drawn from a study population of 100. The respondent draws were carried out using the stratified random sampling technique in the analysis of variances (ANOVA) as used to analyze the data collected by use of a research administered questionnaire. The finding from the analysis indicated that the three main Information and Communication Technology (ICT) projects used in this research which includes ICT Agriculture, ICT for all (Primary and Secondary School) and Closed-Circuit Television (CCTV) Camera show that many of the respondents strongly agreed to ICT for all (Primary and Secondary School) while in ICT Agriculture and Closed-Circuit Television (CCTV) Camera, very few respondents agreed to the ICT project in River state.This study recommends that the authorities should encourage the use, upgrade of existing and introduction of more ICT projects which must comply with the necessary quality assurance tests; such as, if the project meets time, if the project meets Cost, if the project meets scope goals, if the project satisfied the user's needs and if the result of the project meet its objectives. This study has provided an empirical basis for problem solving on the Impact Assessment of Factors Affecting Information Technology Projects in Rivers State.
\end{abstract}

Keywords: Critical Success Factors, ICT, Impact Assessment, Management, Project. ****

\section{INTRODUCTION}

The search for new and more effective ways of meeting user's need with Information Technology has made life much easy for clients to carry on with their day to day dealings, through the use of technologies from computing electronics and telecommunications.

Technology Acceptance Model (TAM) is based on the Theory of Reasoned Action (TRA) and it is related to other theories such as the theory of planned behaviour. TAM explains ICT usage behaviour; what causes users to accept or reject the use of a technology and how user acceptance is affected by system characteristics. In TAM, two theoretical constructs exist. They are perceived usefulness and perceived ease of use. Perceived usefulness is the "degree to which a person believes using a particular system would enhance his or her job performance", while perceived ease refers to "the degree to which a person believes that using a particular system would be free of effort".

[1] Identified nine top critical success factors that would act as enablers for successful implementation of ICT projects. They are cost of development, top management support, availability of appropriate tools, development team knowledge and understanding of construction processes, ease of applications, clear definition and understanding end user, clear communication, standardization issues and change management of organization level.

[2] Emphasized five critical success factors as the project manager, project team, project itself, organization and external environment. [3] identified early and continual client consultation, technology, scheduling system, project team and top management support as the most significant critical success factors. Project summary, operational concept, top management support, financial support, logistic requirements, facility support, market intelligence, project schedule, executive development and training, manpower and organization, acquisition, information and communication channels and project review were identified as critical success factors influencing project performance [4]. Leadership, partnership, proof and clarity of innovative concept, business planning and marketing, triple bottom line planning, short and long term benefits management, community engagement and risk management were also found out as critical success factors in project implementation [5]. 
In a perfect world every IT project would be "on time and within budget." But reality (especially the proven statistics) tells a very different story. It's not uncommon for IT projects to fail. Even if the budget and schedule are met, one must ask "did the project deliver the results and quality we expected?" True project success must be evaluated on all three components. Otherwise, a project could be considered a "failure."
There are many reasons why IT projects (both simple and complex) fail; the number of reasons can be infinite. However, if we apply the 80/20 rule the most common reasons for failure can be found in the following list:

\begin{tabular}{|l|l|l|}
\hline Poorly managed & Undefined objectives and goals & Lack of management commitment \\
\hline Lack of a solid project plan & Lack of user input & Lack of organizational support \\
\hline $\begin{array}{l}\text { Centralized proactive management initiatives } \\
\text { to combat project risk }\end{array}$ & $\begin{array}{l}\text { Enterprise management of budget } \\
\text { resources }\end{array}$ & $\begin{array}{l}\text { Provides universal templates and } \\
\text { documentation }\end{array}$ \\
\hline Poorly defined roles and responsibilities & Inadequate or vague requirements & Stakeholder conflict \\
\hline Team weaknesses & Unrealistic timeframes and tasks & Competing priorities \\
\hline Poor communication & $\begin{array}{l}\text { Insufficient resources (funding and } \\
\text { personnel) }\end{array}$ & Business politics \\
\hline Overruns of schedule and cost & $\begin{array}{l}\text { Estimates for cost and schedule are } \\
\text { erroneous }\end{array}$ & $\begin{array}{l}\text { Lack of prioritization and project portfolio } \\
\text { management }\end{array}$ \\
\hline Scope creep & No change control process & Meeting end user expectations \\
\hline Ignoring project warning signs & Inadequate testing processes & Bad decisions \\
\hline
\end{tabular}

In order to stop the failure of IT project in River State, three IT projects carried out in River State will be examined, to determine the following for a successful IT project:

1. Find out to what extent IT projects met stipulated time.

2. Ascertain the profit - performance of IT project in River State.

3. Determine to what extent users of IT project respond adequately to IT- projects infrastructure.

4. Determine to what extent was IT project an added value to users.

5. To find out the need of frequent training if necessary for effective project delivery.

\section{RESEARCH HYPOTHESIS}

In order to set a good base for carrying out the research, the following hypotheses and questions were posed, believing that by the time adequate answers has been provided, the study would have covered necessary grounds. To achieve this, the study will test five hypotheses in this research. The hypotheses are as follows;

$\mathrm{Ho}_{1}$ : There is no significant difference based on time between the three IT Projects carried out in River State;

$\mathrm{Ho}_{2}$ : There is no significant difference between Profit-performance of the IT projects;

$\mathrm{Ho}_{3}$ : Projects users do not adequately respond to use of IT Project Infrastructure.

$\mathrm{Ho}_{4}$ : A project is not significantly an added value to users / clients.
$\mathrm{Ho}_{5}$ : Frequent training of users / clients is not significantly necessary for effective project delivery.

\section{CONCEPTUAL FRAMEWORK}

\subsection{ICT Projects and Time Specification}

Time in an ICT project is of great significant. Time is used to compare how long an event or a project lasts and to tell when an event occurs [6]. Over time, most of the ICT projects lack time management (the act of planning, controlling and finally executing specific activities, especially to increase efficiency or productivity). The key recommendation is that project timescales should be short, which means that larger systems should be split into separate projects.

\subsection{Profit - Performance of ICT Project}

[7] Reported that corporate performance is empirically measured in terms of turnover growth. The hypothesised relationship between ICT and turnover growth is straightforward: The implementation of new ICT and complementary investments can lead to innovations, and innovations are positively associated with turnover growth. In other words, innovative firms are more likely to grow. This holds for ICT- and for non-ICT-related innovations, as well as for process- and product-innovations. The empirical results support this view and indicate that innovative firms exhibit increasing turnovers significantly more frequently than noninnovative firms. 


\subsection{The Adequacy of User Response to ICT - Project}

\section{Infrastructure}

Access to advanced ICT infrastructure is increasingly vital to the socio-economic well-being of cities and nations in the global knowledge-based economy [8], [9], [10], [11]. Firms, investors, skilled workers, researchers and governments rely on such infrastructure to share information, transact business, innovate, communicate, and work efficiently. The availability of so-called 'intelligent' infrastructure is used increasingly by states and communities to compete for investment and skilled workers [12].

\subsection{ICT Project as an Added Value to Users}

ICT project has contributed to poverty reduction; this lies in its power to give poor women and men access to improved information and communications. ICT, broadly, allows for a reduction in transactions costs, improved communications with markets and within the supply chain, and improved information about new opportunities. More specifically, ICT projects can:

1. Provide reliable access to markets (local, regional and international) through increased use of affordable communications (phone, fax, email).

2. It provides numerous, pathways for a student to discover things all by himself in the process of learning, which can help students to easily recall; opposed to when they only sit down, look and listen.

3. Provide information about locally and internationally available non-financial business development services (BDS) (e.g., training schemes, business skills, and marketing).

4. Provide access to legal information, including information on contract law, tax law, and regulation.

5. Provide improved access to information about financial services, and access to financial services.

6. It encourages collaboration and interaction among students, students and their teachers, and experts from different fields all over the world.

\subsection{Training for Effective ICT Project Delivery}

Computer literacy, outside of literacy itself, is one of the biggest challenges to ICT development in rural areas. Countries implementing ICT for poor communities must remember that training and education are likely to be a necessity in the initial stages. Without them, users may struggle to use the Internet or other ICT applications. The resulting frustration and reduced enthusiasm about new technologies can spread quickly. For new users, education increases both accessibility and confidence.

To support training activities, the Traditional Training Approach [13] [14] or the On the Job Training Approach [15] [16] can be used.

\section{METHOD OF DATA ANALYSIS}

In other to analyse data collected for the study, the five hypotheses were stated using Analysis of Variances (ANOVA). The ANOVA is a parametric statistical tool used to determine whether means score or sample variance on one or more factors differs significantly from each other. In the application of Analysis of Variances, the independent variable may be expressed quantitatively nominal and not quantitatively.

This statistical technique is based on the $\mathrm{F}$ - distribution and it assumes that only one systematic factor influences the variable being studied. In addition, all the populations have the same variance $\delta 2$. It concentrated on the value of a variable and the corresponding values of explanatory variable $\mathrm{X}$. The variable $\mathrm{X}$ is used to only divide $\mathrm{Y}$ into sub - sample. The one way analysis of variance aims at splitting the total variation of a variable into components between - group variation and variation within the samples (within - group variation).

To achieve a desired result the following steps are carried out.

1. State the null and alternative hypotheses

$\mathrm{H}_{0}: \mathrm{B}_{1}=\mathrm{B}_{2}=0$

$\mathrm{H}_{\mathrm{A}}: \mathrm{B}_{1} \neq \mathrm{B}_{2}$

2. Choose the level of significance $=\alpha$

3. Compute the $\mathrm{F} \alpha$ with $(\mathrm{k}-1)$ and $(\mathrm{N}-\mathrm{k})$ degree of freedom from the $\mathrm{F}$ - table

4. Draw the random samples $(n 1, n 2, \ldots, n k=r)$ from each of the $\mathrm{K}$ sample population

5. Computation of $\mathrm{SS}_{\mathrm{T}}$, and $\mathrm{SS}_{\mathrm{B}}$ and $\mathrm{SS}_{\mathrm{w}}$ as $\mathrm{SS}_{\mathrm{T}}-\mathrm{SS}_{\mathbf{B}}$

i. TOTAL SUM OF SQUARES $\left(\mathrm{SS}_{\mathrm{T}}\right)$

This is a measurement of the total variation of the entire set of data. The computation formula is

$$
\mathrm{SS}_{\mathrm{T}}=\sum_{\mathrm{K}=1}^{\mathrm{k}} \sum_{\mathrm{i}=1}^{\mathrm{P}} X_{i k}^{2}-\frac{T^{2}}{N}
$$

Where $\mathrm{T}$ is the overall total of all the $\mathrm{N}$ observation $\mathrm{X}_{\mathrm{ik}}$ is the observation at the $\mathrm{i}^{\text {th }}$ row and $\mathrm{k}^{\text {th }}$ column.

ii. SUM OF SQUARES "BETWEEN GROUP" VARIATION $\left(\right.$ SS $\left._{\mathbf{B}}\right)$

It measure the deviation or variation between the means and the computational formula. It is computed as:

$$
\mathrm{SS}_{\mathrm{B}}=\sum_{k=1}^{k}\left(\frac{T_{k}^{2}}{n_{k}}\right)-\frac{T^{2}}{N}
$$


In this case $T_{k}$ is the total number of observation in $\mathrm{k}^{\text {th }}$ column and $\mathrm{n}$ is the number of observation in the $\mathrm{k}^{\text {th }}$ column.

iii. SUM OF SQUARES WITHIN - GROUP VARIATION $\left(\mathrm{SS}_{\underline{w}}\right)$

The sum of square is sometimes referred to as the error sum of squares and it measure the deviation of the individual observation around their respective sample. It is computed as

$$
\begin{aligned}
& \mathrm{SS}_{\mathrm{W}}=\sum_{\mathrm{k}=1}^{\mathrm{k}} \sum_{\mathrm{i}=1}^{\mathrm{n}} X_{i k}^{2}-\sum_{\mathrm{k}=1}\left(\frac{T_{k}^{2 \mathrm{k}}}{n_{k}}\right) \\
& \mathrm{SS}_{\mathrm{W}}=\mathrm{SS}_{\mathrm{T}}-\mathrm{SS}_{\mathrm{B}}
\end{aligned}
$$

The symbols used in the formulas above are defined as follows $\mathrm{T}=\sum \sum X_{i k}=$ Grand sum i.e Sum of all the scores.

$\mathrm{T}_{\mathrm{k}}=$ Sum of scores in group $\mathrm{k}$

$\mathrm{N}_{\mathrm{k}}=$ Number of scores in group $\mathrm{k}$

$\mathrm{N}=$ Total number of scores

\section{iv COMPUTATION OF THE MEAN SUM OF SQUARES (MS)}

The mean sums of squares (or variance estimates) for within - groups $\left(\mathrm{MS}_{\mathrm{w}}\right)$ and between - group $\left(\mathrm{MS}_{\mathrm{B}}\right)$ are computed by dividing the sums of squares within - groups and between - groups by the corresponding degree of freedom as shown below:
(a) Within - Group Mean Sum of Squares, $\mathrm{MS}_{\mathrm{W}}=$ $\frac{S S_{W}}{N-K}$

(b) Between - Group Sum of Squares, $\mathrm{MS}_{\mathrm{B}}=\frac{S S_{B}}{K-1}$

\begin{tabular}{|c|c|c|c|c|}
\hline $\begin{array}{l}\text { SOURCE OF } \\
\text { VARIANCE }\end{array}$ & $\begin{array}{l}\text { SUM OF SQUARES } \\
\text { (SS) }\end{array}$ & $\begin{array}{l}\text { DEGREE OF } \\
\text { FREEDOM(df) }\end{array}$ & $\begin{array}{l}\text { MEAN } \\
\text { SQUARE (MS) }\end{array}$ & $\begin{array}{l}\text { VARIANCE } \\
\text { RATIO } \\
\text { (F - Ratio) }\end{array}$ \\
\hline 1 & 2 & 3 & $4=(2) /(3)$ & 5 \\
\hline BETWEEN GROUPS & $\mathrm{SS}_{\mathrm{B}}=\sum\left(\frac{T_{k}^{2}}{n_{k}}\right)-\frac{T^{2}}{N}$ & $\mathrm{~K}$ & $M S R=\frac{S S_{B}}{K-1}$ & $F=\frac{M S_{B}}{M S_{W}}$ \\
\hline WITHINGROUPS & $\begin{array}{c}\mathrm{SS}_{\mathrm{W}}=\mathrm{SS}_{\mathrm{T}}-\mathrm{SS}_{\mathrm{B}} \\
S S_{W}\end{array}$ & $\mathrm{n}-\mathrm{k}-1$ & $M S E=\frac{S S_{W}}{N-K}$ & \\
\hline TOTAL & $S S_{T}=\sum \sum X_{i k}^{2}$ & $\mathrm{n}-1$ & - & - \\
\hline
\end{tabular}

THE ANOVA TABLE ONE-WAY ANALYSIS OF VARIANCE (ANOVA) TABLE

\section{vi. DECISION MAKING}

Computation of $\mathrm{F}$ - Ratio, the test statistic employed in ANOVA is the F-statistic. This is computed as the ratio of between - groups mean sum of squares and within - groups mean sum of squares,

$$
\mathrm{F}^{*}=\frac{M S_{B}}{M S_{W}}
$$

Also compare $\mathrm{F}$ - Ratio with $\mathrm{F} \alpha$ and take a decision using the null hypothesis.

$\mathrm{H}_{0}$ is accepted at the a Significance level if

$$
\mathrm{F}^{*}<\mathrm{F}_{\mathrm{i}}-\alpha(\mathrm{K}, \mathrm{n}-\mathrm{k}-1)
$$

Otherwise, $\mathrm{H}_{0}$ is rejected in favor of $\mathrm{H}_{\mathrm{A}}: \mathrm{F}_{\mathrm{i}}-\alpha(\mathrm{K}, \mathrm{n}$ $-\mathrm{k}-1$ ) from the Statistical table

\section{DATA PRESENTATION AND ANALYSIS}

Table 1: Respondents' Categories of Operation and Status

\begin{tabular}{|l|lc|lc|}
\hline & \multicolumn{2}{|l|}{$\begin{array}{l}\text { Questionnaire } \\
\text { Distributed \& The } \\
\text { Percentages }\end{array}$} & \multicolumn{2}{l|}{$\begin{array}{l}\text { Questionnaire } \\
\text { Collected And } \\
\text { Percentages }\end{array}$} \\
\hline $\begin{array}{l}\text { Head of IT } \\
\text { Project }\end{array}$ & 20 & $(25 \%)$ & 17 & $(20 \%)$ \\
\hline Client / users & 80 & $(75 \%)$ & 68 & $(80 \%)$ \\
\hline TOTAL & 100 & $(100 \%)$ & 85 & $(100 \%)$ \\
\hline
\end{tabular}

One Hundred (100) questionnaires were distributed out of which eight- five (85) was returned. And that is $85 \%$ of the 100 questionnaires. From the 85 questionnaires returned, Head of IT projects have $17(20 \%)$ while client / users have 68 $(80 \%)$ 


\subsection{Research Question One}

\subsubsection{To what extent does IT Project Meet Stipulated Time base on the options below}

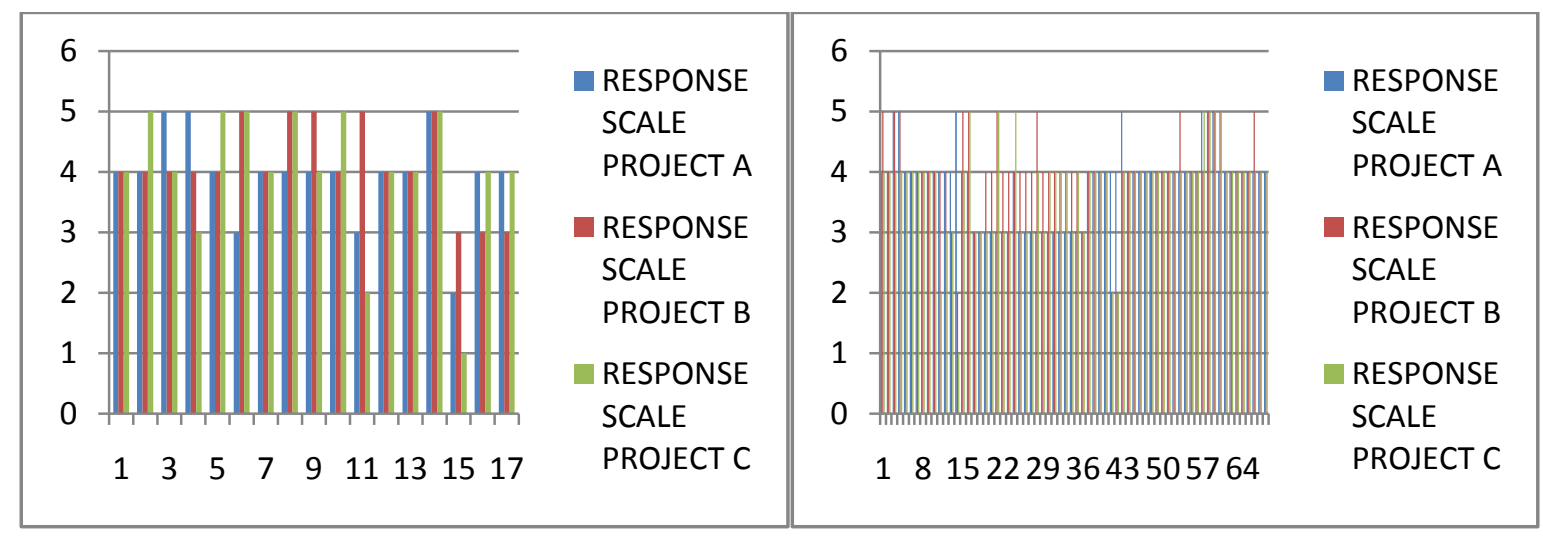

Fig 1: The Extent to Which IT Project Meet Stipulated Time Base Response on Head of IT Project (First Graph) and Clients/Users (Second Graph)

From the graph on Head of ICT, majority agree that project A (ICT IN AGRICULTURE) met stipulated time, For project B (ICT FOR ALL (PRIMARY AND SECONDARY)) almost half responded strongly agree while one or two responded strongly disagree, disagree and undecided. For project $\mathrm{C}$ (Closed - circuit Television (CTTV) Camera), majority also agree that project $\mathrm{C}$ met stipulated time.
From the graph on Users responses, it shows that very few responded strongly agree and disagree, while the majority agree that on project A (ICT IN AGRICULTURE) met stipulated time. For project B (ICT FOR ALL (PRIMARY AND SECONDARY), majority agreed that project $B$ met stipulated time. For project $\mathrm{C}$, almost half responded strongly agree and one or two responses on strongly disagree, disagree and undecided, while the majority agree that project $\mathrm{C}$ met stipulated time.

\subsection{Research Question Two}

\subsubsection{What are the Profit-Performances of IT Projects in River State}

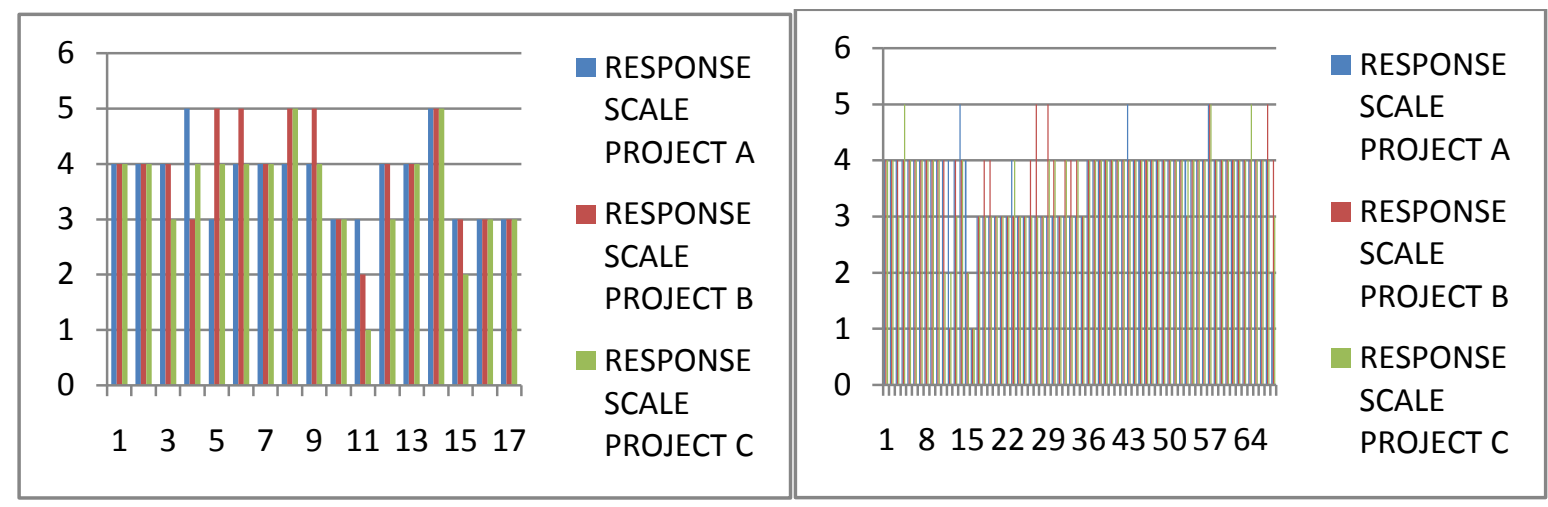

Fig 2: What are the profit-performances of IT project in River state response based on head of IT project (First Graph) and Client/Users (Second graph)

From the graph on Head of ICT, majority agree that all three projects met profit-performance of IT.

From the graph on users of ICT on project A, three responses were strongly agree, one response disagree and few undecided.
For project B (ICT FOR ALL (PRIMARY AND SECONDARY)), majority agree that project $\mathrm{B}$ profit performance of IT was met. Then for project C (Closed circuit Television (CCTV) Camera), majority also agree that project $\mathrm{C}$ profit - performance of IT was met. 


\subsection{Research Question Three}

\subsubsection{To What Extent Do Users of IT Projects Respond Adequately To IT-Projects Infrastructures?}

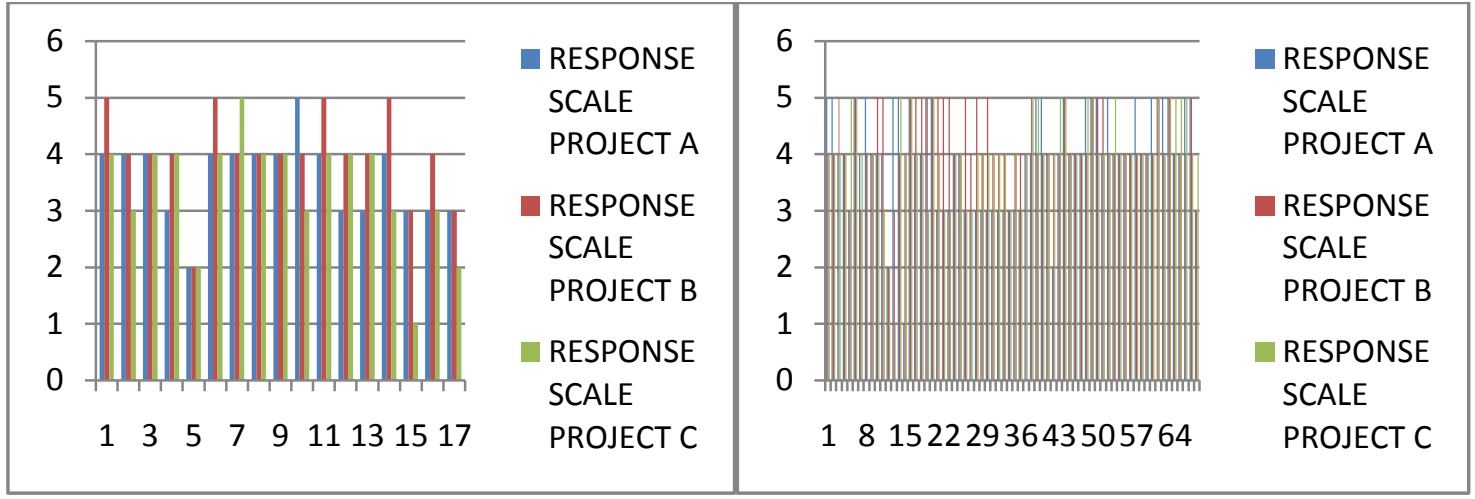

Fig 3: To what extent do users of IT project response adequately to IT-Projects infrastructure response based on head of IT project (First Graph) and Client/Users (Second graph)

From the graph on Head of ICT on project A (ICT IN AGRICULTURE), one responded strongly agree, one responded disagree and few undecided, while the majority agree to the adequately use of IT- projects infrastructure. For project B (ICT FOR ALL (PRIMARY AND SECONDARY)), four responses strongly agree and two undecided responses. Then for project $\mathrm{C}$ (Closed - circuit Television (CCTV)
Camera) majority agree to the adequately use of IT- projects infrastructure.

From the graph on users of ICT, majority agree to the adequately use of IT- projects infrastructure for all three projects.

\subsection{Research Question Four}

\subsubsection{To What Extent Was IT Project An Added Value To Users?}

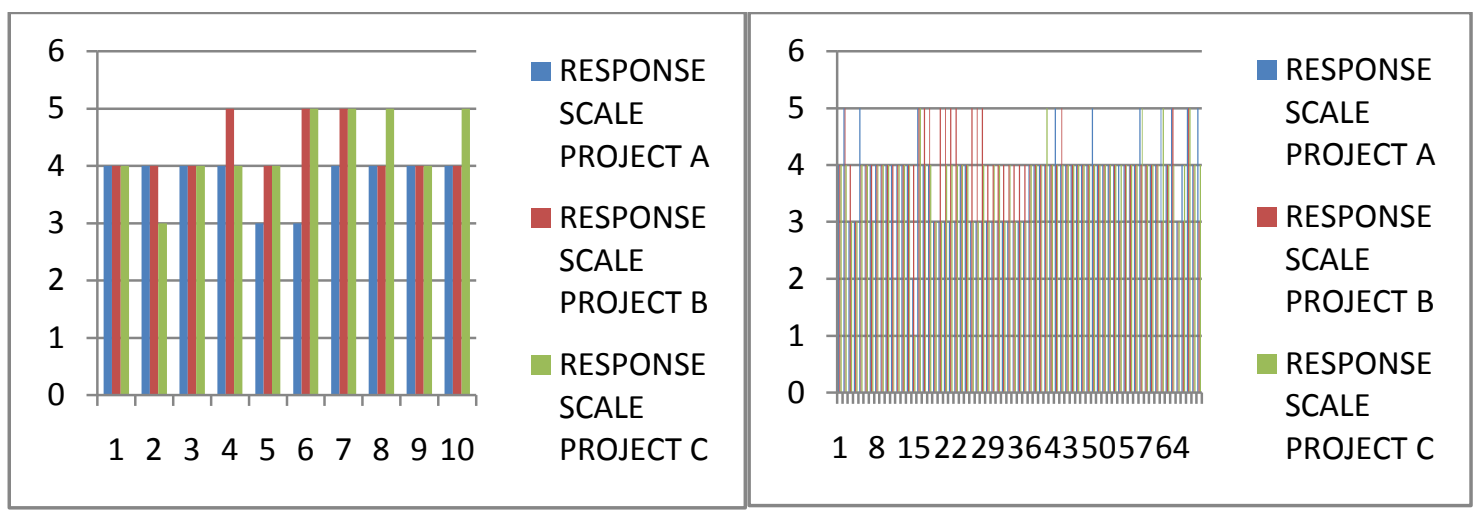

Fig 4: To what extent was IT project an added value to users response based on head of IT project (First Graph) and Client/Users (Second graph)

From the graph on Head of ICT, it shows that on all the three projects (A, B and C), majority agree that IT was an added value to users.

From the graph on users of ICT, it shows that on project A (ICT IN AGRICULTURE), ten responded strongly agree, one responded disagree and many responses were undecided. For project B (ICT FOR ALL (PRIMARY AND SECONDARY)) fourteen responses strongly agree and five undecided responses, while the majority agree that IT was an added value to users. Then for project $\mathrm{C}$ (Closed - circuit Television (CCTV) Camera), majority agree that IT was an added value to users. 


\subsection{Research Question Five}

\subsubsection{To What Extent Were The Need of Frequent Training Necessary For Effective Project Delivery?}

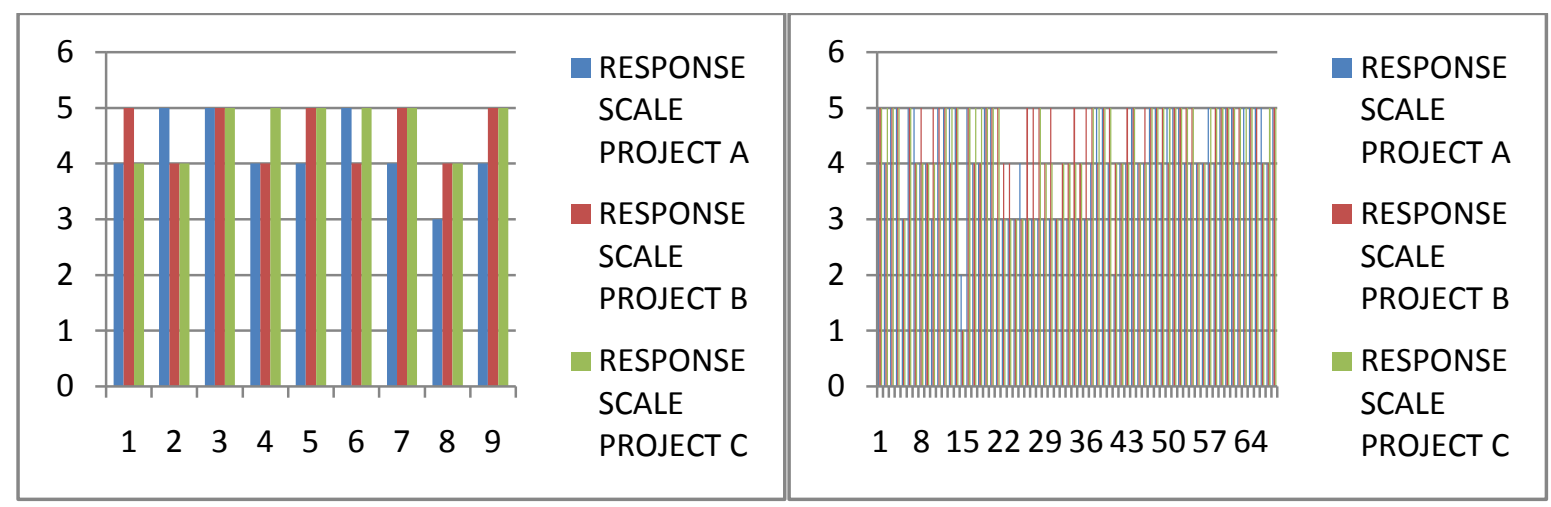

For both graphs, majority of the respondent agree that there are needs of frequent training necessary for effective project delivery on all three projects.

\section{SUMMARY}

After a careful and thorough analysis of the collected data, the following findings were made;-

1. In ICT in agriculture, very little responded strongly agreed to the effective use of ICT project while majority does not agree to effective implantation of ICT project in agriculture.

2. In ICT for all (primary and secondary), there was very high response to strongly agreed to the effective use of ICT project while very little does not agree to effective implantation of ICT for all (primary and secondary).

3. In Closed - circuit Television (CCTV) Camera, very little responded strongly agreed to the effective use of ICT project while majority does not agree to effective implantation of Closed-circuit Television (CCTV) Camera.

\section{CONCLUSIONS}

The findings from the case study have indicated that the ICT project in the state has a minimal impact. The state has to encourage introducing more ICT projects and make sure that user and clients of ICT get the best benefit of ICT project.

\section{RECOMMENDATIONS}

Information Technology (IT) project planning should begin as soon as the need is identified, preferably well in advance of the fiscal year in which funds are to be expended. In developing the plan, a matrix team consisting of all those who will be responsible for significant aspects of the project should be formed. At key dates specified in the plan or whenever significant changes occur and no less often than annually, the matrix team shall review the plan and, if appropriate, revise it. Urgent or unrealistic delivery or performance schedules should always be avoided since it generally restricts competition and increases prices.

The project plan shall be formally approved and consist of a Feasibility study, solicitation plan and post implementation review. If the plan proposes using other than full and open competition when awarding a contract, the plan shall also include a sole source/ sole brand justification.

\section{REFERENCES}

[1] Ugwu, O. and Kumaraswang, M. (2007). Critical success factor for construction of ICT projectssome empirical evidence and lessons for emerging economies. IT conference paper, 12:231-249.

[2] Belassi, W. and Tukei, O. (1996). A new framework for determining critical success / failure factors in projects. International Journal of Project Management, 14(3):141-152.

[3] Pinto, J. and Kharbanda, O. (1995). Successful Project Mangers: Leading your team to success. New York: Van Nostrance Reinhold.

[4] Cleland, D. and King, W. (1983). Systematic Analysis and Project Management. New York: McGraw-Hill.

[5] Boyer, D., Creech, H., and Paas, L. (2008). Critical success factors and performance measures for start-up social and environmental enterprises. International Institute for Sustainable Development, SEED Initiative Research Program.

[6] Encarta Premium DVD (2009). English Dictionaries. Retrieved May 21, 2011. http://top.windows9download.net/list/encarta-premiumdictionary-2009.html

[7] Philipp Koellinger (2006). Impact of ICT on Corporate Performance, Productivity and Employment Dynamics: 
European Commission Enterprise \& Industry Directorate General Technology for Innovation / ICT Industries and e-Business

[8] Bleha, T. (2005). Down to the Wire. Foreign Affairs, 84(3), 111-124.

[9] 9.Castells, M. (1989). The Informational City: Information Technology, Economic Restructuring, and the Urban-Regional Process. Oxford, UK; Cambridge, Mass., USA: B. Blackwell.

[10] Sassen, S. (2002). Global Networks, Linked Cities. New York: Routledge.

[11] Wilhelm, A. G. (2004). Digital Nation: Toward an Inclusive Information Society. Cambridge: MIT Press.

[12] Caves, R. W., \& Walshok, M. G. (1999). Adopting Innovations in Information Technology: The California Municipal Experience. Cities, 16(1), 3-12

[13] Beaver, G. and Hutchings, K. (2005). Training and developing an age diverse workforce in SMEs: The need for a strategic approach, Education and Training, 47(8/9): 592-604.

[14] Smith, D. and Vaughan, S. (1997). The outdoors as an environment for learning and change management', Industrial and Commercial Training, 29(1): 26-30.

[15] Dickson, D, Hargie, O and Morrow, N. (1997). Communication Skills Learning for Health Professionals', Chapman \& Hall, London

[16] Neville, K. (2004). A Government Crossing the Digital Divide to Promote ICT for Adult Learners, Electronic Journal of e-Learning, 2(1): 145-158. 